\title{
Scalar Cross-Relaxation Detected in the NOESY Spectra of Oxazolidines and Thiazolidines
}

Tharindi D. Panduwawala, ${ }^{\dagger, \S}$ Laia Josa-Culleré, ${ }^{\dagger, \S}$ Ilya Kuprov, ${ }^{\dagger}$ Barbara Odell, ${ }^{\dagger}$ Mark G. Moloney, ${ }^{*} \dagger$ and Timothy D. W. Claridge*, $\dagger$

${ }^{\dagger}$ Department of Chemistry, Chemistry Research Laboratory, University of Oxford, Mansfield Road, Oxford OX1 3TA, U.K.

${ }^{\ddagger}$ School of Chemistry, University of Southampton, Highfield Campus, Southampton SO17 1BJ, U.K.

Supporting Information

ABSTRACT: Anomalous cross-peaks observed in the NOESY spectra of 2,4-disubstituted thiazolidines and oxazolidines that cannot be attributed to classical dipolar NOE or chemical exchange peaks have been investigated experimentally and computationally and have been shown to arise from scalar cross-relaxation of the first kind. This process is stimulated by the relatively slow modulation of scalar couplings and, for the systems studied, arises from slow on-off proton exchange of the amino nitrogen, a process influenced by solution temperature, acidity, and concentration. The mechanism is likely to be significant for many systems in which proton exchange occurs on the millisecond time scale, and misinterpretation of these cross-peaks may lead to erroneous conclusions should their true origins not be recognized.
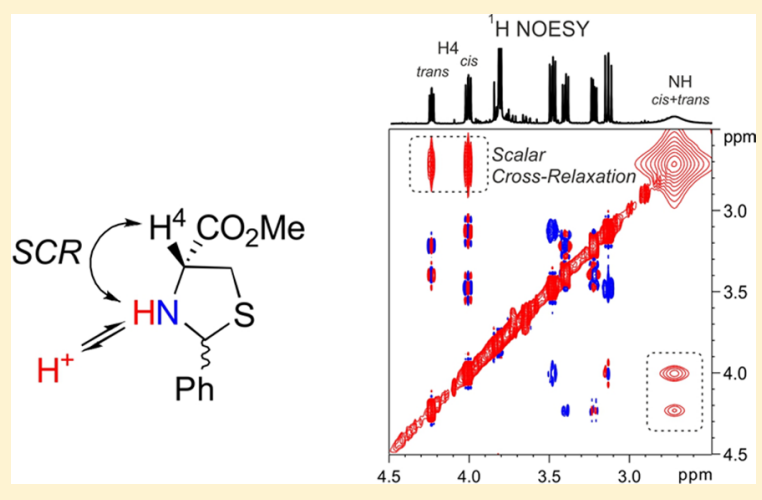

\section{INTRODUCTION}

Nitrogen heterocycles comprise the core structural subunit in many alkaloids, and impart wide ranging biological and pharmaceutical activities. ${ }^{1,2}$ We have been interested in the elaboration of amino acid esters 1-3 to oxazolidines/ thiazolidines cis- $\mathbf{4}$ and trans- $\mathbf{4}$ (where cis and trans defines the relative stereochemistry for the two positions adjacent to the ring nitrogen) and their use in turn as templates to direct aldol and Dieckmann ring annulation processes (Scheme 1$).^{3-5}$ This chemistry may be applied to systems derived from serine $\mathbf{1}$, ${ }^{4,5}$ threonine $2,{ }^{6,7}$ and cysteine $3,{ }^{8}$ and the success of these processes critically depends on ring-chain tautomerism, ${ }^{9-12}$ which permits equilibration between cis and trans diastereomers 4, ultimately leading to the more stable product in which both substituents are pseudoequatorial, which is especially preferred when $\mathrm{R}^{\prime}=t-\mathrm{Bu}$; this approach has shown synthetic value in the construction of antibacterial chemical libraries. ${ }^{13}$

During the synthesis of the oxazolidines and thiazolidines, prepared using literature protocols, ${ }^{4-8}$ mixtures of cis and trans diastereomers 4 were produced in ratios of $\sim 1: 1$, which were difficult to separate by standard column chromatography. In the course of assigning the relative stereochemistry of these isomers, we were surprised to observe anomalous cross-peaks in $2 \mathrm{D}$ NOESY spectra that could not be explained by conventional analysis, as exemplified for $\mathbf{4 d}$ (Figure 1). This spectrum is unusual because in addition to the negative cross-peaks (colored blue) between $\mathrm{CH}$ protons indicative of the classical throughspace nuclear Overhauser effect ${ }^{14,15}$ a number of strong positive cross-peaks (colored red) are also observed. Conventionally, for small molecules that do not aggregate, such peaks would be suggestive of chemical exchange occurring between correlated protons, ${ }^{16}$ but here these are between protons that cannot possibly exchange with each other. Herein we rationalize the origin of these effects as arising from scalar cross-relaxation of the first kind (SCRFK), a process shown to be driven by $\mathrm{NH}$ proton exchange in these molecules. We believe it is likely that others will observe similar effects in NOE spectra in the presence of proton exchange and we present our investigations on the appearance of this effect in the title compounds to draw wider attention to this phenomenon.

\section{RESULTS AND DISCUSSIONS}

In a previous publication, ${ }^{17}$ anomalous NOESY cross-peaks similar to those in Figure 1 but observed for C-substituted aziridines could not be explained by dipolar cross-relaxation or chemical exchange and were shown, through experimental and computational studies, to arise from scalar relaxation of the first kind. The requirement for the associated scalar cross-relaxation process to occur, and be able to effectively compete with the dipolar cross-relaxation that is responsible for the classical NOE, is a modulation, on a millisecond time scale, of the coupling constant between $J$-coupled protons, such that the rate of longitudinal scalar cross-relaxation (expressed in eq 1) becomes significant: ${ }^{17,18}$

Received: March 2, 2016

Published: May 5, 2016 
Scheme 1. Thiazolidines $(\mathrm{X}=\mathrm{S})$ and Oxazolidines $(\mathrm{X}=\mathrm{O})$ Derived from Amino Acids and Aldehydes and the Corresponding Product Ratios in the Systems Studied by NMR

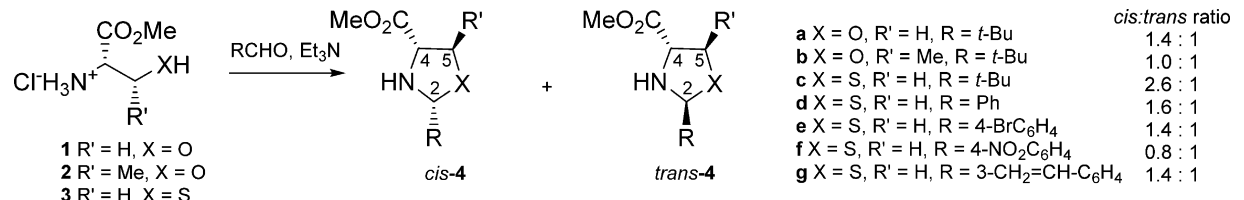

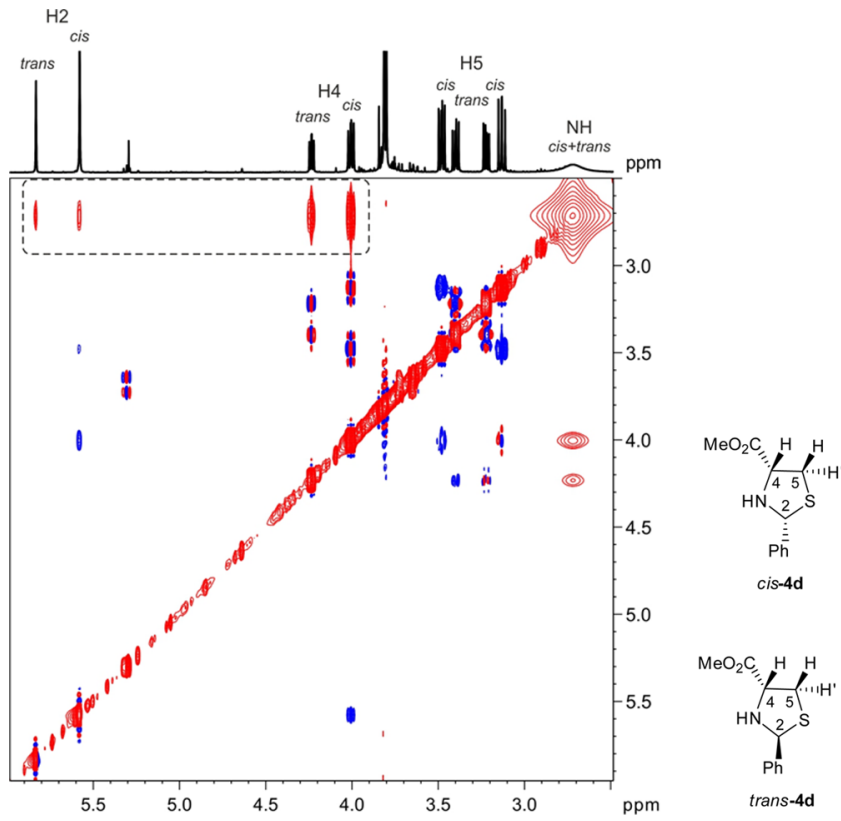

Figure 1. ${ }^{1} \mathrm{H}-{ }^{1} \mathrm{H}$ NOESY spectrum of $\mathbf{4 d}$ as $1.6: 1$ cis:trans mixture $\left(\mathrm{CDCl}_{3}, 298 \mathrm{~K}, 500 \mathrm{MHz}, 800 \mathrm{~ms}\right.$ mixing time), showing anomalous strong positive cross-peaks (red) between the $\mathrm{NH}$ protons and those of the neighboring $\mathrm{CH}$ groups (boxed region).

$$
\left\langle\hat{S}_{\mathrm{Z}}^{(1)}\left|\hat{\hat{R}}_{\mathrm{SRFK}}\right| \hat{S}_{\mathrm{Z}}^{(2)}\right\rangle=\frac{\Delta_{J}^{2} \tau_{\mathrm{ex}}}{2} \frac{1}{1+\left(\omega_{1}-\omega_{2}\right)^{2} \tau_{\mathrm{ex}}^{2}} \approx \frac{\Delta_{J}^{2} \tau_{\mathrm{ex}}}{2}
$$

This expression shows that the cross-relaxation rate depends upon the size of modulation of scalar coupling constant $\left(\Delta_{I}\right)$, its rate of change (reflected in the lifetime of exchanging states $\tau_{\mathrm{ex}}$ ) and the frequency separation between the $J$-coupled protons $\left(\omega_{1}-\omega_{2}\right)$ in the ${ }^{1} \mathrm{H}$ spectrum. The effect is expected to be most pronounced for coupled protons with similar chemical shifts and where large modulations of coupling constants may occur. Notably, it gives rise to cross-peaks that have opposite sign to the NOEs typically observed for small molecules.

The NOESY spectrum of $\mathbf{4 d}$ could be calculated theoretically using the Spinach simulation program ${ }^{19-21}$ to reproduce the anomalous cross peaks of Figure 1 only when scalar crossrelaxation was included between the $\mathrm{NH}$ protons and their $J$ coupled neighbors $\mathrm{H} 2$ and $\mathrm{H} 4$ (Figure 2); without this term only classical dipolar NOEs were reproduced (see Supporting Information for details and Figure S1).

In the case of the aziridines, ${ }^{17}$ this scalar cross-relaxation process was shown theoretically to arise from the modulation of ${ }^{1} \mathrm{H}-{ }^{1} \mathrm{H} J$-couplings of $\mathrm{NH}$ protons through conformational transitions involving nitrogen inversion. This is known to be relatively slow in aziridines due to the high inversion energy barriers involved $\left(\sim 70 \mathrm{~kJ} \mathrm{~mol}^{-1}\right)$, and hence gave rise to $J$ -

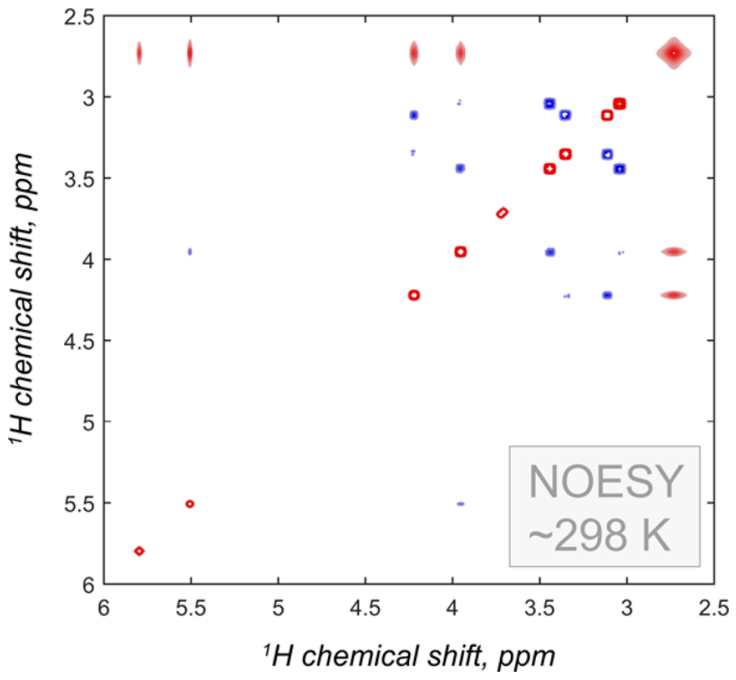

Figure 2. Simulated ${ }^{1} \mathrm{H}-{ }^{1} \mathrm{H}$ NOESY spectrum of $4 \mathrm{~d}$ (800 ms mixing time), exactly reproduces the positive cross-peaks of Figure 1 only when scalar cross-relaxation of the first kind is considered between the amino protons and their J-coupled neighbors. Molecular geometries were obtained from DFT calculations, while chemical shifts and J-couplings of the individual cis and trans isomers were extracted from the experimental 1D NMR spectra. The proton exchange rate at the nitrogen center was set to $500 \mathrm{~s}^{-1}$, overall rotational correlation time to $30 \mathrm{ps}$, nitrogen inversion correlation time to $100 \mu \mathrm{s}$, and modulation depth of $J$-coupling between the amino proton and the protons at $\mathrm{C} 2$ and $\mathrm{C} 4$ was set to 15 $\mathrm{Hz}$ (see main text for discussion of these parameters).

modulation rates appropriate for SCRFK to be operational and able to compete with the dipolar NOE.

We could find no reports on nitrogen inversion barriers in thiazolidines and oxazolidines in which the nitrogen is not fully substituted, although the free energy of activation for nitrogen inversion in $N$-methylthiazolidine is reported to be $35.9 \mathrm{~kJ} \mathrm{~mol}^{-1}$ (at the exchange coalescence temperature of $173 \mathrm{~K}){ }^{22}$ The inversion barrier in pyrrolidine is $25 \mathrm{~kJ} \mathrm{~mol}^{-1},{ }^{23}$ very much lower than in aziridines, and likely to be similar to those in oxazolidines and thiazolidines such as 4 . DFT calculations of the nitrogen inversion barrier do indeed suggest this to be the case (see Supporting Information), which places the nitrogen inversion time scale in the microsecond region at ambient temperatures. Such rates are too high to give rise to significant scalar crossrelaxation, and thus nitrogen inversion is not an appropriate mechanism to yield cross-peaks for the oxazolidine and thiazolidine systems which have $\mathrm{NH}$ proton scalar couplings of $<15 \mathrm{~Hz}$. Consistent with the absence of slow nitrogen inversion, only a single set of resonances was ever observed experimentally for each diastereoisomer of $\mathbf{4 d}$ studied over a wide temperature range ( 193 to $298 \mathrm{~K}$ ), and resonances from separate invertomers were never detected (in contrast to the aziridines where these were fully resolved in ${ }^{1} \mathrm{H}$ NMR spectra at $193 \mathrm{~K}^{17}$ ). This suggests that the process by which $J$-couplings are modulated to give rise 
(a)

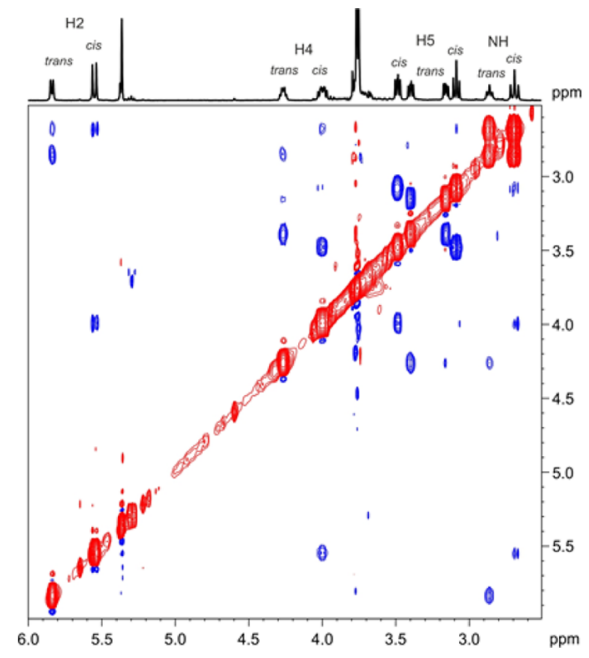

(b)

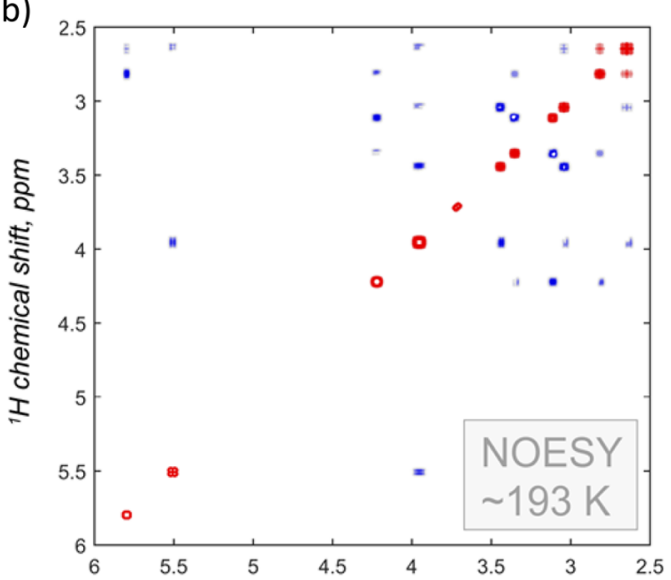

Figure 3. ${ }^{1} \mathrm{H}-{ }^{1} \mathrm{H}$ NOESY spectrum ( $800 \mathrm{~ms}$ mixing time) of compound $4 \mathrm{~d}$. (a) Mixture of cis/trans diastereoisomers in 1.6:1 ratio in $\mathrm{CD}_{2} \mathrm{Cl}_{2}$ at $193 \mathrm{~K}$, showing only dipolar NOE (blue) and chemical exchange (red) cross-peaks. (b) A simulated NOESY spectrum $\left(\tau_{\mathrm{c}}=300\right.$ ps), calculated using exchange rate constants of 0.25 and $0.5 \mathrm{~s}^{-1}$ (for cis and trans isomers, respectively) which reproduces all observed cross-peaks.

Scheme 2. Likely Proton Exchange Mechanisms in Thiazolidines $(X=S)$ and Oxazolidines $(X=O)^{a}$

(a)

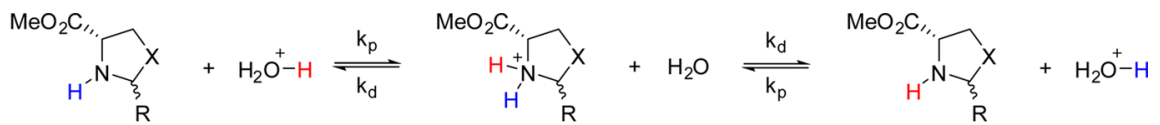

(b)

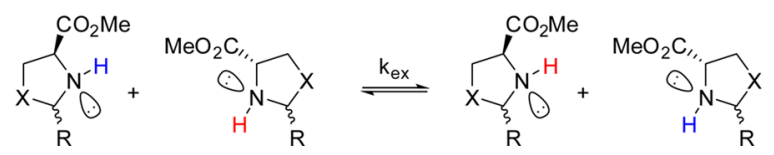

${ }^{a}$ (a) acid catalysed proton exchange; (b) bimolecular proton exchange.

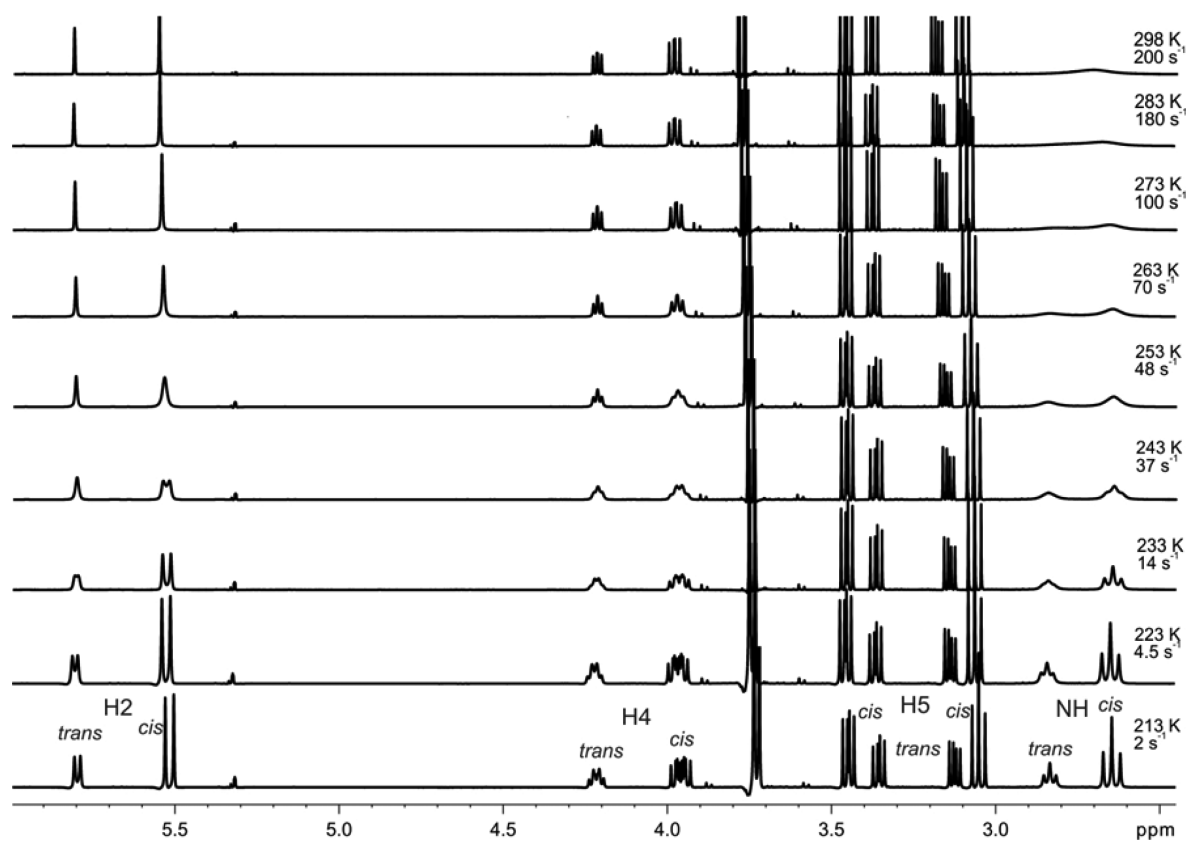

Figure 4. Variable temperature ${ }^{1} \mathrm{H}$ NMR spectra of $4 \mathrm{~d}$ in dried and degassed $\mathrm{CD}_{2} \mathrm{Cl}_{2}$ at $90 \mathrm{mM}$. The rate constants for two-site exchange between $\mathrm{NH}$ protons of the two diastereoisomers were determined by line shape fitting, with the lower rate constant listed.

to scalar cross-relaxation for $\mathbf{4 d}$ must involve a different mechanism than direct nitrogen $\mathrm{NH}$ inversion.

Similar NOESY spectra exhibiting scalar cross-relaxation peaks between $\mathrm{NH}$ protons and adjacent $\mathrm{CH}$ protons were observed for variously substituted thiazolidines and oxazolidines when studied at room temperature (see Figure S2). It was noticeable that the appearance of these cross-peaks was correlated with the presence of broad $\mathrm{NH}$ resonances without resolved J-coupling 


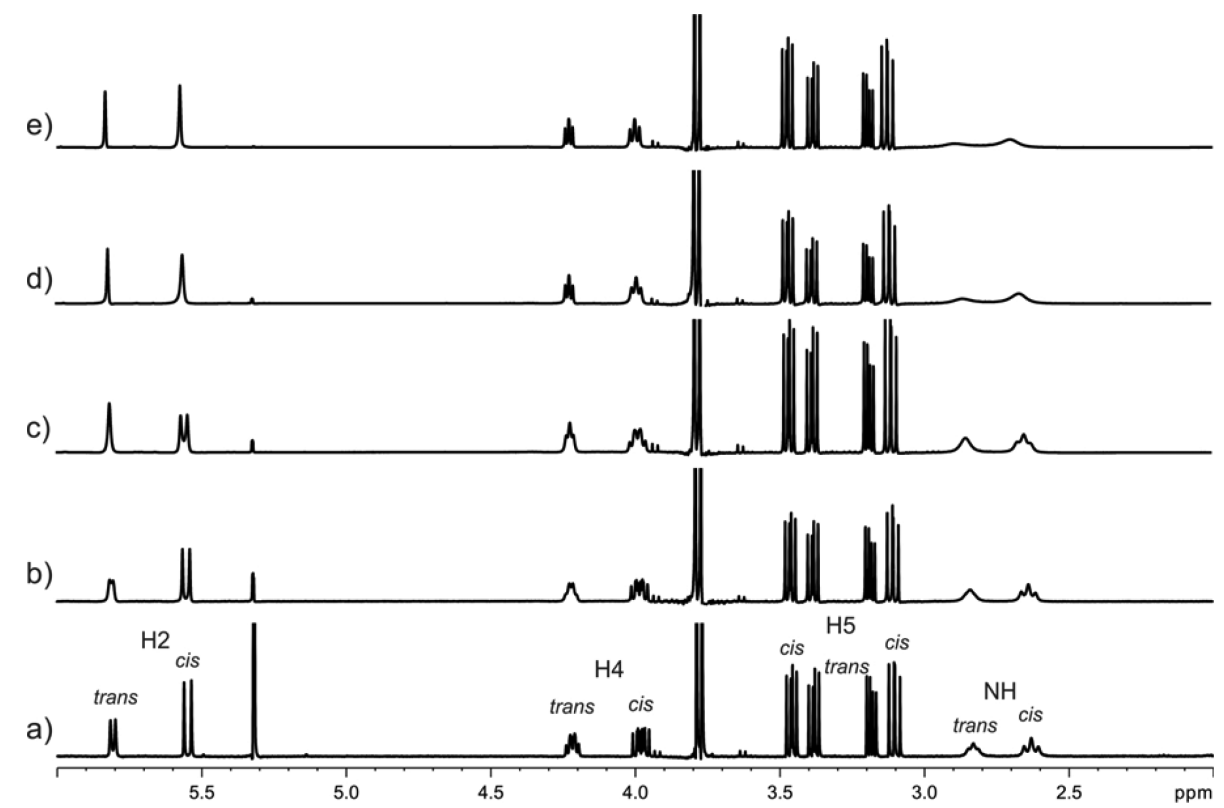

Figure 5. Concentration dependence of the NMR spectra of compound $4 \mathrm{~d}$ at $298 \mathrm{~K}$ in $\mathrm{CD}_{2} \mathrm{Cl}_{2}$. (a) $8 \mathrm{mM}$; (b) $90 \mathrm{mM}$; (c) $270 \mathrm{mM}$; (d) $450 \mathrm{mM}$; (e) $900 \mathrm{mM}$.

structure for both cis and trans isomers; when the coupling fine structures of these resonances were well resolved, the anomalous cross-peaks were not seen. For example, the ${ }^{1} \mathrm{H}$ spectrum of $\mathbf{4 d}$ recorded at $193 \mathrm{~K}$ showed clear $\mathrm{NH}$ coupling structure and the NOESY spectrum contained only intramolecular dipolar NOE peaks and chemical exchange peaks between the amino protons of the separate diastereoisomers, indicating these undergo slow intermolecular exchange (Figure 3). This suggests a likely process to cause modulation of $J$-couplings in the five-membered ring is a nitrogen protonation-deprotonation process, which could involve both acid-catalyzed and bimolecular pathways, in which water may also play a contributing role (Scheme 2 ). In the context of the SCRFK process, this would lead to variation of the scalar coupling since the incoming proton spin-state is uncorrelated with those of the remaining protons in the ring, a process also known to give rise to a loss of coupling structure, and often referred to as "exchange decoupling". This process is clearly apparent in the variable temperature spectra of $\mathbf{4 d}$ (Figure 4) where, as the $\mathrm{NH}$ resonances broaden, their coupling structure with the $\mathrm{H} 2$ and $\mathrm{H} 4$ resonances is progressively lost. Lineshape simulations of the spectra (Figure S3) provided estimates of the $\mathrm{NH}$ exchange rates between cis/trans diastereoisomers, which would likely be similar to those for exchange between similar stereoisomers (cis/cis or trans/trans) that would not normally be apparent in ${ }^{1} \mathrm{H}$ NMR spectra. These rates were used in simulations of NOESY spectra of $\mathbf{4 d}$ to demonstrate the dependence on the scalar relaxation process on kinetic parameters (Figure S4), and these data clearly illustrate the progressive increase in SCRFK cross-peaks as the exchange rate increases and the $\mathrm{NH} J$-coupling structure collapses. These data suggest that at rates below $\sim 50 \mathrm{~s}^{-1}$, SCRFK becomes inconsequential, while for rates at or above $\sim 200 \mathrm{~s}^{-1}$ (i.e., similar to those observed experimentally under ambient temperature conditions; Figure 4) this process is significant and gives rise to strong scalar cross-relaxation cross-peaks, as seen in Figure 1. In accord with this behavior, we have also observed that in situations when $\mathrm{NH}$ peaks display well-resolved multiplet structures and no SCRFK cross-peaks in NOESY spectra, their appearance can be stimulated by raising the sample temperature to increase exchange rates such that $\mathrm{NH}$ coupling structure collapses. This may also be accompanied by evidence for $\mathrm{NH}$ exchange with residual water in the solvent (classical chemical exchange cross-peaks), as was observed for $\mathbf{4 g}$ in toluene (Figure S5). It is also worth noting that for the chemical systems described here, the HN-H4 SCRFK cross-peaks always appear more intense than those for $\mathrm{HN}-\mathrm{H} 2$ correlations, despite the similar J-coupling constants and the influence of identical exchange processes. This is a consequence of the smaller chemical shift separation in the case of $\mathrm{HN}-\mathrm{H} 4$ and is consistent with the behavior anticipated from eq 1 .

The proposed protonation-deprotonation cross-relaxation mechanism has been previously reported. Over 40 years ago, Fukumi et al. concluded that $J$-couplings were responsible for the sign change observed in the cross-relaxation rate between the $\mathrm{OH}$ and the $\mathrm{CH}$ protons in methanol ${ }^{24}$ and ethanol ${ }^{25}$ when acid concentration was varied. The corresponding theory originates from $1956,{ }^{18}$ but, until recently, ${ }^{17}$ it appears that clear experimental manifestations of the process in molecules larger than HF, methanol, and ethanol are rare enough (or unusual enough) for the process to be commonly overlooked during NOESY data analysis. We believe this to be the first reported evidence for $\mathrm{NH}$ proton exchange yielding cross-peaks in NOESY spectra due to scalar cross-relaxation of the first kind.

Our investigations into these systems also demonstrated the appearance of these effects to be acutely sensitive to solution conditions, and specifically those that may influence $\mathrm{NH}$ exchange rates. For example, different batches of the $\mathrm{CD}_{2} \mathrm{Cl}_{2}$ solvent (prepared in different countries) gave different results: those that showed coalesced NH signals and SCRFK peaks in NOESY were suspected to contain traces of acid, whereas those that did not show these peaks were presumed to be less acidic. Consequently, the addition of trace amounts of deuterated acetic acid to the latter solutions of $\mathbf{4 d}(0.01 \% \mathrm{v} / \mathrm{v})$ was able to reintroduce these cross-peaks (Figure S6). The influence of traces of acid in sample workup procedures was also investigated in detail for $\mathbf{4 d}$ where samples were dissolved in EtOAc and 


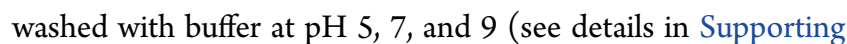
Information). Only the sample subjected to the $\mathrm{pH} 5$ buffer gave rise to the SCRFK cross-peaks, while those from the higher $\mathrm{pH}$ buffers did not (Figure S7). Scalar cross-relaxation peaks were observed across a range of solvents including $\mathrm{CD}_{2} \mathrm{Cl}_{2}, \mathrm{CDCl}_{3}$, $\mathrm{C}_{6} \mathrm{D}_{6}$, and toluene, although the exception was DMSO which appeared to inhibit these peaks, likely due to hydrogen-bonding perturbing the $\mathrm{NH}$ exchange process.

The likely involvement of bimolecular exchange was also seen to influence the proton spectrum of $\mathbf{4 d}$ as a function of solution concentration (Figure 5). An increase was seen to lead to broadening of the $\mathrm{NH}$ resonance of both isomers with corresponding exchange decoupling of neighboring protons, indicative of an increase in exchange rate. Correspondingly, scalar cross-relaxation cross-peaks were observed only at the higher concentration for this sample. Slight shift changes are also apparent in the spectra of Figure 5 as a function of concentration, most notably for the $\mathrm{NH}$ and the adjacent $\mathrm{CH}$ protons, which suggests association, potentially through intermolecular hydrogen bonding involving amino and carbonyl groups. Such association may promote the bimolecular exchange process and serve to enhance the appearance of scalar cross-relaxation. Thus, sample concentration will also likely dictate conditions under which scalar cross-relaxation peaks may be seen in NOESY spectra when proton exchange is involved, alongside temperature and solvent acidity.

\section{CONCLUSIONS}

The appearance of anomalous cross-peaks in the NOESY spectra of oxazolidines and thiazolidines has been attributed to scalar cross-relaxation of the first kind that arises when the J-couplings between correlated protons are slowly modulated. These crosspeaks have opposite sign to positive NOEs and an appearance similar to chemical exchange peaks, although they do not arise between mutually exchanging protons. For these systems, they are shown to arise from proton on-off exchange at the amino nitrogen which leads to modulation of proton scalar couplings, and their appearance is therefore sensitive to solution conditions that will influence this exchange rate, including sample temperature, solution acidity, and solute concentration. The presence of such peaks in (1D and 2D) NOESY spectra will likely occur in any system in which scalar couplings are modulated at an appropriate rate (on the millisecond time scale), with likely mechanisms including conformational interconversion, nitrogen inversion, and proton exchange.

\section{EXPERIMENTAL SECTION}

Synthesis. General Procedure for the Synthesis of Oxazolidine and Thiazolidine Compounds. ${ }^{26}$ To the relevant methyl ester hydrochloride (1.0 equiv) in petroleum ether, triethylamine (1.5 equiv) and aldehyde (1.2 equiv) were added. The mixture was heated at reflux with continuous removal of water using a Dean-Stark head for 18 h. The white precipitate was then filtered and washed with $\mathrm{Et}_{2} \mathrm{O}$. The combined filtrates were concentrated under reduced pressure to give the oxazolidine or thiazolidine. All aryl substituted thiazolidines were purified by flash column chromatography $\left(\mathrm{SiO}_{2}, \mathrm{EtOAc} /\right.$ Petroleum ether).

Methyl (2RS,4S)-2-(tert-Butyl)-1,3-oxazolidine-4-carboxylate $(4 a) .^{27,28}$ Yield (5.85 g, 97\%); yellow oil; inseparable 1.4:1 cis and trans diastereomers. $R_{\mathrm{f}}$ (85\% EtOAc in DCM) 0.64; ${ }^{1} \mathrm{H}$ NMR (400 $\mathrm{MHz}, \mathrm{CDCl}_{3}$ ) major isomer (cis): $\delta 4.07(\mathrm{~s}, 1 \mathrm{H}, \mathrm{H} 2), 3.89-3.97(\mathrm{~m}, 2 \mathrm{H}$, $\left.\mathrm{H}_{\mathrm{A}}+\mathrm{H} 4\right), 3.76\left(\mathrm{~s}, 3 \mathrm{H}, \mathrm{CO}_{2} \mathrm{CH}_{3}\right), 3.68-3.72\left(\mathrm{~m}, 1 \mathrm{H}, \mathrm{H} 5_{\mathrm{B}}\right), 2.61(\mathrm{br} \mathrm{s}$ $1 \mathrm{H}, \mathrm{NH}$, averaged with trans isomer $\mathrm{NH}), 0.98\left(\mathrm{~s}, 9 \mathrm{H}, \mathrm{C}\left(\mathrm{CH}_{3}\right)_{3}\right)$; minor isomer (trans): $4.32(\mathrm{~s}, 1 \mathrm{H}, \mathrm{H} 2), 4.11\left(\operatorname{app~t}, 1 \mathrm{H}, J=7.6 \mathrm{~Hz}, \mathrm{H} 5_{\mathrm{A}}\right)$,
3.89-3.97 (m, 1H, H4), $3.74\left(\mathrm{~s}, 3 \mathrm{H}, \mathrm{CO}_{2} \mathrm{CH}_{3}\right), 3.68-3.72(\mathrm{~m}, 1 \mathrm{H}$, $\left.\mathrm{H}_{\mathrm{B}}\right), 2.61(\mathrm{br} \mathrm{s}, 1 \mathrm{H}, \mathrm{NH}$,- averaged with cis isomer $\mathrm{NH}), 0.91(\mathrm{~s}, 9 \mathrm{H}$, $\left.\mathrm{C}\left(\mathrm{CH}_{3}\right)_{3}\right) ;{ }^{13} \mathrm{C}\left\{{ }^{1} \mathrm{H}\right\}$ NMR $\left(100 \mathrm{MHz}, \mathrm{CDCl}_{3}\right)$ major isomer (cis): $\delta$ $173.0\left(\mathrm{CO}_{2} \mathrm{CH}_{3}\right), 100.0(\mathrm{C} 2), 68.4(\mathrm{C} 4), 59.6(\mathrm{C}), 52.7\left(\mathrm{CO}_{2} \mathrm{CH}_{3}\right)$, $33.3\left(\mathrm{C}\left(\mathrm{CH}_{3}\right)_{3}\right)$, $25.3\left(\mathrm{C}\left(\mathrm{CH}_{3}\right)_{3}\right)$; minor isomer (trans): 173.2 $\left(\mathrm{CO}_{2} \mathrm{CH}_{3}\right), 99.3$ (C2), 69.0 (C4), 59.5 (C5), $52.5\left(\mathrm{CO}_{2} \mathrm{CH}_{3}\right), 34.6$ $\left(\mathrm{C}\left(\mathrm{CH}_{3}\right)_{3}\right)$, $25.0\left(\mathrm{C}\left(\mathrm{CH}_{3}\right)_{3}\right)$; IR (neat) $\nu_{\max } / \mathrm{cm}^{-1} 3316,2955,1740$; HRMS (TOF, ESI $\left.{ }^{+}\right) \mathrm{m} / z:[\mathrm{M}+\mathrm{H}]^{+}$Calcd for $\mathrm{C}_{9} \mathrm{H}_{18} \mathrm{NO}_{3}$ 188.1281; Found 188.1285.

Methyl (2RS,4S,5R)-2-(tert-Butyl)-5-methyl-1,3-oxazolidine-4-carboxylate (4b). Yield (1.84 g, 77\%); yellow oil; inseparable 1:1 diastereomers. $R_{\mathrm{f}}\left(50 \%\right.$ EtOAc in DCM) $0.64 ;{ }^{1} \mathrm{H}$ NMR $(400 \mathrm{MHz}$, $\left.\mathrm{CDCl}_{3}\right)(2 \mathrm{R}, 4 \mathrm{~S}, 5 \mathrm{R})$ isomer: $\delta 4.29(\mathrm{~s}, 1 \mathrm{H}, \mathrm{H} 2), 3.78-3.88(\mathrm{~m}, 1 \mathrm{H}, \mathrm{H} 5)$, $3.75\left(\mathrm{~s}, 3 \mathrm{H}, \mathrm{CO}_{2} \mathrm{CH}_{3}\right), 3.46(\mathrm{~d}, 1 \mathrm{H}, J=7.2 \mathrm{~Hz}, \mathrm{H} 4), 2.69(\mathrm{br} \mathrm{s}, 1 \mathrm{H}, \mathrm{NH}$, averaged with $2 \mathrm{~S}, 4 \mathrm{~S}, 5 \mathrm{R}$ isomer $\mathrm{NH}), 1.33\left(\mathrm{~d}, 3 \mathrm{H}, J=6.0 \mathrm{~Hz}, \mathrm{C}(5) \mathrm{CH}_{3}\right)$, $0.97\left(\mathrm{~s}, 9 \mathrm{H}, \mathrm{C}\left(\mathrm{CH}_{3}\right)_{3}\right)$; $(2 \mathrm{~S}, 4 \mathrm{~S}, 5 \mathrm{R})$ isomer: $4.38(\mathrm{~s}, 1 \mathrm{H}, \mathrm{H} 2), 3.78-3.88$ (m, $1 \mathrm{H}, \mathrm{H} 5), 3.77\left(\mathrm{~s}, 3 \mathrm{H}, \mathrm{CO}_{2} \mathrm{CH}_{3}\right), 3.36(\mathrm{~d}, 1 \mathrm{H}, J=7.2 \mathrm{~Hz}, \mathrm{H} 4), 2.69$ (br s, $1 \mathrm{H}, \mathrm{NH}$, averaged with $2 \mathrm{R}, 4 \mathrm{~S}, 5 \mathrm{R}$ isomer $\mathrm{NH}), 1.37$ (d, $3 \mathrm{H}, J=6.0$ $\left.\mathrm{Hz}, \mathrm{C}(5) \mathrm{CH}_{3}\right), 0.90\left(\mathrm{~s}, 9 \mathrm{H}, \mathrm{C}\left(\mathrm{CH}_{3}\right)_{3}\right) ;{ }^{13} \mathrm{C}\left\{{ }^{1} \mathrm{H}\right\}$ NMR $(100 \mathrm{MHz}$, $\left.\mathrm{CDCl}_{3}\right)(2 \mathrm{R}, 4 \mathrm{~S}, 5 \mathrm{R})$ isomer: $\delta 172.1\left(\mathrm{CO}_{2} \mathrm{CH}_{3}\right), 98.9(\mathrm{C} 2), 76.4(\mathrm{C} 5)$,

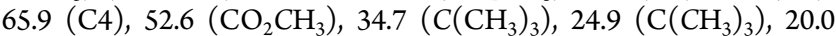
$\left(\mathrm{C}(5) \mathrm{CH}_{3}\right)$; (2S,4S,5R) isomer: $172.8\left(\mathrm{CO}_{2} \mathrm{CH}_{3}\right), 98.3(\mathrm{C} 2), 77.4$

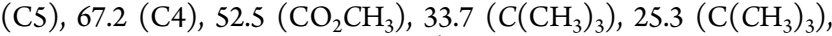
$19.1\left(\mathrm{C}(5) \mathrm{CH}_{3}\right)$; IR (neat) $\nu_{\max } / \mathrm{cm}^{-1} 3315,2957,1741$; HRMS (TOF, $\left.\mathrm{ESI}^{+}\right) \mathrm{m} / z:[\mathrm{M}+\mathrm{Na}]^{+}$Calcd for $\mathrm{C}_{10} \mathrm{H}_{19} \mathrm{NNaO}_{3}$ 224.1257; Found 224.1266.

Methyl (2RS,4S)-2-(tert-Butyl)-1,3-thiazolidine-4-carboxylate (4c). ${ }^{29}$ Yield (2.32 g, 98\%); yellow oil; inseparable 2.6:1 cis and trans diastereomers. $R_{\mathrm{f}}\left(75 \%\right.$ EtOAc in DCM) $0.61 ;{ }^{1} \mathrm{H}$ NMR $(500 \mathrm{MHz}$, $\mathrm{CDCl}_{3}$ ) major isomer (cis): $\delta 4.43(\mathrm{~s}, 1 \mathrm{H}, \mathrm{H} 2), 3.78(\mathrm{dd}, 1 \mathrm{H}, J=9.7,6.7$ $\mathrm{Hz}, \mathrm{H} 4), 3.75\left(\mathrm{~s}, 3 \mathrm{H}, \mathrm{CO}_{2} \mathrm{CH}_{3}\right), 3.23\left(\mathrm{t}, 1 \mathrm{H}, J=10.2,6.7 \mathrm{~Hz}, \mathrm{H}_{\mathrm{A}}\right), 2.65$ $\left(\mathrm{t}, 1 \mathrm{H}, J=10.0 \mathrm{~Hz}, \mathrm{HS}_{\mathrm{B}}\right), 2.40(\mathrm{br} \mathrm{s}, 1 \mathrm{H}, \mathrm{NH}$, averaged with trans isomer $\mathrm{NH}), 1.04\left(\mathrm{~s}, 9 \mathrm{H}, \mathrm{C}\left(\mathrm{CH}_{3}\right)_{3}\right)$; minor isomer (trans): $4.50(\mathrm{~s}, 1 \mathrm{H}, \mathrm{H} 2)$, $4.11(\mathrm{t}, 1 \mathrm{H}, J=6.0 \mathrm{~Hz}, \mathrm{H} 4), 3.72\left(\mathrm{~s}, 3 \mathrm{H}, \mathrm{CO}_{2} \mathrm{CH}_{3}\right), 3.08(\mathrm{t}, 1 \mathrm{H}, J=10.6$, $\left.6.4 \mathrm{~Hz}, \mathrm{HS}_{\mathrm{A}}\right), 2.99\left(\mathrm{dd}, 1 \mathrm{H}, J=10.6,5.6 \mathrm{~Hz}, \mathrm{HS}_{\mathrm{B}}\right), 2.40(\mathrm{br} \mathrm{s}, 1 \mathrm{H}, \mathrm{NH}$, averaged with cis isomer $\mathrm{NH}), 0.95\left(\mathrm{~s}, 9 \mathrm{H}, \mathrm{C}\left(\mathrm{CH}_{3}\right)_{3}\right) ;{ }^{13} \mathrm{C}\left\{{ }^{1} \mathrm{H}\right\} \mathrm{NMR}$ $\left(100 \mathrm{MHz}, \mathrm{CDCl}_{3}\right)$ major isomer (cis): $\delta 171.9\left(\mathrm{CO}_{2} \mathrm{CH}_{3}\right), 81.9(\mathrm{C} 2)$, 65.5 (C4), $52.5\left(\mathrm{CO}_{2} \mathrm{CH}_{3}\right), 37.5$ (C5), $34.1\left(\mathrm{C}\left(\mathrm{CH}_{3}\right)_{3}\right), 27.1$ $\left(\mathrm{C}\left(\mathrm{CH}_{3}\right)_{3}\right)$; minor isomer (trans): $172.5\left(\mathrm{CO}_{2} \mathrm{CH}_{3}\right), 79.9(\mathrm{C} 2), 65.1$ (C4), $52.5\left(\mathrm{CO}_{2} \mathrm{CH}_{3}\right), 37.1(\mathrm{C} 5), 36.0\left(\mathrm{C}\left(\mathrm{CH}_{3}\right)_{3}\right), 26.7\left(\mathrm{C}\left(\mathrm{CH}_{3}\right)_{3}\right)$; IR (neat) $\nu_{\max } / \mathrm{cm}^{-1} 3317,2954,1740$; HRMS (TOF, ESI $\left.{ }^{+}\right) \mathrm{m} / z:[\mathrm{M}$ $+\mathrm{Na}]^{+}$Calcd for $\mathrm{C}_{9} \mathrm{H}_{17} \mathrm{NNaO}_{2} \mathrm{~S}$ 226.0872; Found 226.0880.

Methyl (2RS,4R)-2-Phenyl-1,3-thiazolidine-4-carboxylate (4d). Yield (2.37 g, 91\%); colorless oil; inseparable 1.6:1 cis and trans diastereomers; $R_{\mathrm{f}}\left(25 \%\right.$ ethyl acetate in petroleum ether) 0.48 ; ${ }^{1} \mathrm{H}$ NMR $\left(500 \mathrm{MHz}, \mathrm{CDCl}_{3}\right)$ major isomer (cis): $\delta 7.56-7.47$ and $7.41-7.31(\mathrm{~m}$, $5 \mathrm{H}, \mathrm{Ar}-\mathrm{CH}$ ), 5.57 (s, $1 \mathrm{H}, \mathrm{H} 2$ ), 3.99 (dd, $1 \mathrm{H}, J=9.0,7.0 \mathrm{~Hz}, \mathrm{H} 4), 3.80$ (s, $\left.3 \mathrm{H}, \mathrm{CO}_{2} \mathrm{CH}_{3}\right), 3.47\left(\mathrm{dd}, 1 \mathrm{H}, J=10.43,7.0 \mathrm{~Hz}, \mathrm{HS}_{\mathrm{A}}\right), 3.12(\mathrm{dd}, 1 \mathrm{H}, J$ $=10.3,9.0 \mathrm{~Hz}, \mathrm{H}_{\mathrm{B}}$ ), 2.70 (br. $\mathrm{s}, 1 \mathrm{H}, \mathrm{NH}$, averaged with trans isomer $\mathrm{NH})$; minor isomer (trans): $\delta 7.41-7.31(\mathrm{~m}, 5 \mathrm{H}, \mathrm{Ar}-\mathrm{CH}), 5.82(\mathrm{~s}, 1 \mathrm{H}$, $\mathrm{H} 2), 4.22(\mathrm{dd}, 1 \mathrm{H}, J=7.1,5.8 \mathrm{~Hz}, \mathrm{H} 4), 3.79\left(\mathrm{~s}, 3 \mathrm{H}, \mathrm{CO}_{2} \mathrm{CH}_{3}\right), 3.39(\mathrm{dd}$, $\left.1 \mathrm{H}, J=10.6,7.1 \mathrm{~Hz}, \mathrm{HS}_{\mathrm{A}}\right), 3.21\left(\mathrm{dd}, 1 \mathrm{H}, J=10.6,5.8 \mathrm{~Hz}, \mathrm{HS}_{\mathrm{B}}\right.$ ), 2.70 (br. s, $1 \mathrm{H}, \mathrm{NH}$, averaged with cis isomer $\mathrm{NH}) ;{ }^{13} \mathrm{C}\left\{{ }^{1} \mathrm{H}\right\} \mathrm{NMR}(100 \mathrm{MHz}$, $\mathrm{CDCl}_{3}$ ) major isomer (cis): $\delta 171.6\left(\mathrm{CO}_{2} \mathrm{CH}_{3}\right), 138.2(\mathrm{Ar}-\mathrm{C}), 128.7$, 128.5, 127.5 (Ar- $\mathrm{CH}), 70.9$ (C2), $64.3(\mathrm{C} 4), 52.6\left(\mathrm{CO}_{2} \mathrm{CH}_{3}\right), 39.2$ (C5); minor isomer (trans): $\delta 172.2\left(\mathrm{CO}_{2} \mathrm{CH}_{3}\right), 141.2(\mathrm{Ar}-\mathrm{C}), 128.7$, 127.9, $127.0(\mathrm{Ar}-\mathrm{CH}), 72.6(\mathrm{C} 2), 65.6(\mathrm{C} 4), 52.6\left(\mathrm{CO}_{2} \mathrm{CH}_{3}\right), 38.2$ (C5); IR (neat) $\nu_{\max } / \mathrm{cm}^{-1} 3314,2952,1736$; HRMS (TOF, ESI ${ }^{+}$) $\mathrm{m} / z$ : $[\mathrm{M}+\mathrm{Na}]^{+}$Calcd for $\mathrm{C}_{11} \mathrm{H}_{13} \mathrm{NNaO}_{2} \mathrm{~S} 246.0559$; Found 246.0563 .

Methyl (2RS,4R)-2-(4-Bromophenyl)-1,3-thiazolidine-4-carboxylate (4e). Yield (5.60 g, 94\%); colorless oil; inseparable 1.4:1 cis and trans diastereomers; $R_{\mathrm{f}}\left(20 \%\right.$ ethyl acetate in petroleum ether) $0.23 ;{ }^{1} \mathrm{H}$ $\operatorname{NMR}\left(500 \mathrm{MHz}, \mathrm{C}_{6} \mathrm{D}_{6}\right)$ major isomer $(c i s): \delta 7.39(\mathrm{~d}, 2 \mathrm{H}, J=8.5 \mathrm{~Hz}$, $\mathrm{Ar}-\mathrm{CH}), 7.30(\mathrm{~d}, 2 \mathrm{H}, J=8.4 \mathrm{~Hz}, \mathrm{Ar}-\mathrm{CH}), 5.40(\mathrm{~s}, 1 \mathrm{H}, \mathrm{H} 2), 3.87$ (app $\mathrm{t}, 1 \mathrm{H}, J=7.9 \mathrm{~Hz}, \mathrm{H} 4), 3.70\left(\mathrm{~s}, 3 \mathrm{H}, \mathrm{CO}_{2} \mathrm{CH}_{3}\right), 3.35(\mathrm{dd}, 1 \mathrm{H}, J=10.4,7.1$ $\left.\mathrm{Hz}, \mathrm{H} 5_{\mathrm{A}}\right), 3.00\left(\mathrm{dd}, 1 \mathrm{H}, J=10.3,8.9 \mathrm{~Hz}, \mathrm{H}_{\mathrm{B}}\right.$ ), $2.90-2.32$ (br. s, $1 \mathrm{H}$, $\mathrm{NH}$, averaged with trans isomer $\mathrm{NH}$ ); minor isomer (trans): $\delta 7.34(\mathrm{~d}$, $2 \mathrm{H}, J=8.5 \mathrm{~Hz}, \mathrm{Ar}-\mathrm{CH}), 7.26(\mathrm{~d}, 2 \mathrm{H}, J=8.4 \mathrm{~Hz}, \mathrm{Ar}-\mathrm{CH}), 5.66(\mathrm{~s}, 1 \mathrm{H}$, $\mathrm{H} 2$ ), 4.03 (app t, $1 \mathrm{H}, J=6.5 \mathrm{~Hz}, \mathrm{H} 4), 3.69$ (s, 3H, $\mathrm{CO}_{2} \mathrm{CH}_{3}$ ), 3.27 (dd, $\left.1 \mathrm{H}, J=10.6,7.1 \mathrm{~Hz}, \mathrm{H}_{\mathrm{A}}\right), 3.06\left(\mathrm{dd}, 1 \mathrm{H}, J=10.6,6.1 \mathrm{~Hz}, \mathrm{H} 5_{\mathrm{B}}\right), 2.90-$ 
2.32 (br. s, $1 \mathrm{H}, \mathrm{NH}$, averaged with cis isomer $\mathrm{NH}) ;{ }^{13} \mathrm{C}\left\{{ }^{1} \mathrm{H}\right\}$ NMR (100 $\left.\mathrm{MHz}, \mathrm{CDCl}_{3}\right)$ major isomer (cis): $\delta 171.4\left(\mathrm{CO}_{2} \mathrm{CH}_{3}\right), 137.2,122.5$ ( $\mathrm{Ar}-\mathrm{C}), 131.7,129.1(\mathrm{Ar}-\mathrm{CH}), 71.0(\mathrm{C} 2), 65.4(\mathrm{C} 4), 52.6\left(\mathrm{CO}_{2} \mathrm{CH}_{3}\right)$, 39.1 (C5); minor isomer (trans): $\delta 172.0\left(\mathrm{CO}_{2} \mathrm{CH}_{3}\right), 140.5,121.6(\mathrm{Ar}-$ C), 131.3, 128.6 (Ar- $\mathrm{CH}), 69.8(\mathrm{C} 2), 64.0(\mathrm{C} 4), 52.5\left(\mathrm{CO}_{2} \mathrm{CH}_{3}\right), 38.0$ (C5); IR (neat) $\nu_{\max } / \mathrm{cm}^{-1} 3313,2951,1737$; HRMS (TOF, $\left.\mathrm{ESI}^{+}\right) \mathrm{m} / z$ : $[\mathrm{M}+\mathrm{H}]^{+}$Calcd for $\mathrm{C}_{11} \mathrm{H}_{13} \mathrm{O}_{2} \mathrm{NBrS} 301.9845$ and 303.9824; Found 301.9841 and 303.9818.

Methyl (2RS,4R)-2-(4-Nitrophenyl)-1,3-thiazolidine-4-carboxylate (4f). ${ }^{8}$ Yield (2.95 g, 94\%); yellow oil; inseparable 0.8:1 cis and trans diastereomers; $R_{\mathrm{f}}$ (25\% ethyl acetate in petroleum ether) $0.20 ;{ }^{1} \mathrm{H}$ NMR $\left(500 \mathrm{MHz}, \mathrm{CDCl}_{3}\right)$ major isomer (trans): $\delta 8.15(\mathrm{~d}, 2 \mathrm{H}, J=8.8 \mathrm{~Hz}, \mathrm{Ar}-$ $\mathrm{CH}), 7.63(\mathrm{~d}, 2 \mathrm{H}, J=8.5 \mathrm{~Hz}, \mathrm{Ar}-\mathrm{CH}), 5.88(\mathrm{~s}, 1 \mathrm{H}, \mathrm{H} 2), 4.08($ app t, $1 \mathrm{H}$, $J=6.6 \mathrm{~Hz}, \mathrm{H} 4), 3.80\left(\mathrm{~s}, 3 \mathrm{H}, \mathrm{CO}_{2} \mathrm{CH}_{3}\right), 3.39-3.35\left(\mathrm{~m}, 1 \mathrm{H}, \mathrm{HS}_{\mathrm{A}}\right), 3.16-$ $3.11\left(\mathrm{~m}, 1 \mathrm{H}, \mathrm{H} 5_{\mathrm{B}}\right), 2.65$ (br. s, $\left.1 \mathrm{H}, \mathrm{NH}\right)$; minor isomer $($ cis $): \delta 8.20(\mathrm{~d}$, $2 \mathrm{H}, J=8.8 \mathrm{~Hz}, \mathrm{Ar}-\mathrm{CH}), 7.69(\mathrm{~d}, 2 \mathrm{H}, J=8.5 \mathrm{~Hz}, \mathrm{Ar}-\mathrm{CH}), 5.60(\mathrm{~s}, 1 \mathrm{H}$, $\mathrm{H} 2$ ), 4.02 (app t, $1 \mathrm{H}, J=8.0 \mathrm{~Hz}, \mathrm{H} 4), 3.81\left(\mathrm{~s}, 3 \mathrm{H}, \mathrm{CO}_{2} \mathrm{CH}_{3}\right), 3.48$ (dd, $\left.1 \mathrm{H}, J=10.4,7.0 \mathrm{~Hz}, \mathrm{H}_{\mathrm{A}}\right), 3.16-3.11\left(\mathrm{~m}, 1 \mathrm{H}, \mathrm{H}_{\mathrm{B}}\right.$ ), 3.05 (br. $\mathrm{s}, 1 \mathrm{H}$, $\mathrm{NH}) ;{ }^{13} \mathrm{C}\left\{{ }^{1} \mathrm{H}\right\} \mathrm{NMR}\left(100 \mathrm{MHz}, \mathrm{CDCl}_{3}\right)$ major isomer (trans): $\delta 171.7$ $\left(\mathrm{CO}_{2} \mathrm{CH}_{3}\right), 149.5,145.5(\mathrm{Ar}-\mathrm{C}), 127.5,123.5(\mathrm{Ar}-\mathrm{CH}), 69.0(\mathrm{C} 2)$, 64.1 (C4), $52.6\left(\mathrm{CO}_{2} \mathrm{CH}_{3}\right), 38.1$ (C5); minor isomer (cis): $\delta 171.2$ $\left(\mathrm{CO}_{2} \mathrm{CH}_{3}\right), 147.7,147.1(\mathrm{Ar}-\mathrm{C}), 128.4,123.7(\mathrm{Ar}-\mathrm{CH}), 70.9(\mathrm{C} 2)$, $65.3(\mathrm{C} 4), 52.6\left(\mathrm{CO}_{2} \mathrm{CH}_{3}\right), 39.0$ (C5); IR (neat) $\nu_{\text {max }} / \mathrm{cm}^{-1} 3316,1730$, 1516, 1348; HRMS (TOF, $\left.\mathrm{ESI}^{+}\right) \mathrm{m} / z:[\mathrm{M}+\mathrm{Na}]^{+}$Calcd for $\mathrm{C}_{11} \mathrm{H}_{12} \mathrm{~N}_{2} \mathrm{NaO}_{4} \mathrm{~S}$ 291.0410; Found 291.0405.

Methyl (2RS,4R)-2-(3-Vinylphenyl)-1,3-thiazolidine-4-carboxylate (4g). Yield (5.60 g, 84\%); colorless oil; inseparable 1.4:1 cis and trans diastereomers; $R_{\mathrm{f}}\left(20 \%\right.$ ethyl acetate in petroleum ether) $0.43 ;{ }^{1} \mathrm{H}$ NMR $\left(400 \mathrm{MHz}, \mathrm{CDCl}_{3}\right.$ ) major isomer (cis): $\delta 7.60-7.28(\mathrm{~m}, 4 \mathrm{H}, \mathrm{Ar}-\mathrm{CH})$, 6.79-6.69 (m, 1H, H1 $\left.{ }^{\prime}\right), 5.86-5.75\left(\mathrm{~m}, 1 \mathrm{H}, \mathrm{H}_{2}{ }_{\mathrm{B}}{ }^{2}\right), 5.58(\mathrm{~d}, 1 \mathrm{H}, J=12.2$ $\mathrm{Hz}, \mathrm{H} 2), 5.33-5.26\left(\mathrm{~m}, 1 \mathrm{H}, \mathrm{H}_{2}{ }_{\mathrm{A}}\right), 4.07-3.97(\mathrm{~m}, 1 \mathrm{H}, \mathrm{H} 4), 3.83(\mathrm{~s}, 3 \mathrm{H}$, $\left.\mathrm{CO}_{2} \mathrm{CH}_{3}\right), 3.49\left(\mathrm{dd}, 1 \mathrm{H}, J=10.3,7.1 \mathrm{~Hz}, \mathrm{HS}_{\mathrm{A}}\right), 3.14(\mathrm{dd}, 1 \mathrm{H}, J=10.3$, $\left.9.1 \mathrm{~Hz}, \mathrm{HS}_{\mathrm{B}}\right), 2.70($ app t, $1 \mathrm{H}, J=12.2 \mathrm{~Hz}, \mathrm{NH})$; minor isomer (trans): $\delta$ 7.60-7.28 (m, 4H, Ar-CH), 6.79-6.69 (m, 1H, H1'), 5.86-5.75 (m, $\left.2 \mathrm{H}, \mathrm{H} 2+\mathrm{H}^{\prime}{ }_{\mathrm{B}}\right), 5.33-5.26\left(1 \mathrm{H}, \mathrm{m}, \mathrm{H}_{2}{ }_{\mathrm{A}}\right), 4.28-4.20(\mathrm{~m}, 1 \mathrm{H}, \mathrm{H} 4)$, $3.82\left(\mathrm{~s}, 3 \mathrm{H}, \mathrm{CO}_{2} \mathrm{CH}_{3}\right), 3.41\left(\mathrm{dd}, 1 \mathrm{H}, J=10.5,7.1 \mathrm{~Hz}, \mathrm{HS}_{\mathrm{A}}\right), 3.23(\mathrm{dd}$, $\left.1 \mathrm{H}, J=10.8,5.9 \mathrm{~Hz}, \mathrm{HS}_{\mathrm{B}}\right), 2.93-2.84(1 \mathrm{H}$, broad signal, $\mathrm{NH}) ;{ }^{13} \mathrm{C}\left\{{ }^{1} \mathrm{H}\right\}$ $\operatorname{NMR}\left(100 \mathrm{MHz}, \mathrm{CDCl}_{3}\right)$ major isomer (cis): $\delta 171.5\left(\mathrm{CO}_{2} \mathrm{CH}_{3}\right), 138.3$, 138.0 (Ar-C), $136.3\left(\mathrm{Cl}^{\prime}\right), 128.8,126.8,126.4,125.3(\mathrm{Ar}-\mathrm{CH}), 114.5$ (C2'), $72.4(\mathrm{C} 2)$, $65.5(\mathrm{C} 4), 52.5\left(\mathrm{CO}_{2} \mathrm{CH}_{3}\right), 39.1(\mathrm{C} 5)$; minor isomer (trans): $\delta 172.1\left(\mathrm{CO}_{2} \mathrm{CH}_{3}\right), 141.4,137.7(\mathrm{Ar}-\mathrm{C}), 136.5\left(\mathrm{Cl}^{\prime}\right), 128.5$, 126.3, 125.6, 124.8 ( $\mathrm{Ar}-\mathrm{CH}), 114.2\left(\mathrm{C}^{\prime}\right), 70.6(\mathrm{C} 2), 64.2(\mathrm{C} 4), 52.5$ $\left(\mathrm{CO}_{2} \mathrm{CH}_{3}\right), 38.0$ (C5); IR (neat) $\nu_{\max } / \mathrm{cm}^{-1} 3305,2951,1737$; HRMS (TOF, $\left.\mathrm{ESI}^{+}\right) \mathrm{m} / z$ : $[\mathrm{M}+\mathrm{H}]^{+}$Calcd for $\mathrm{C}_{13} \mathrm{H}_{16} \mathrm{O}_{2} \mathrm{NS}$ 250.0896; Found 250.0890 .

NMR Spectroscopy. NMR data were collected at $500 \mathrm{MHz}\left({ }^{1} \mathrm{H}\right)$ with sample temperatures over the range $193-373 \mathrm{~K}$ as stated. Samples were dissolved in dry $\mathrm{C}_{6} \mathrm{D}_{6}, \mathrm{CD}_{2} \mathrm{Cl}_{2}, \mathrm{DMSO}-d_{6}$, or toluene- $d_{8}$ and characterized by ${ }^{1} \mathrm{H}, \mathrm{COSY}$, edited-HSQC, and ${ }^{13} \mathrm{C}$ NMR. 2D NOESY spectra were collected using standard pulse programs $\left(90-\mathrm{t}_{1}-90-\tau_{\mathrm{m}}-90-\right.$ Acq, without or with a purging bipolar gradient pulse pair $\left(+G_{1}[180]\right.$ $\mathrm{G}_{1}$ ) at the midpoint of the mixing period, $\tau_{\mathrm{m}}$ ) with mixing times of 800 $\mathrm{ms}$ at the temperatures and in the solvents stated. For each data set, 8 or 16 transients were acquired for each of the 256 increments with $2 \mathrm{~K}$ data points per spectrum, using a recovery time of $2 \mathrm{~s}$. Data were processed typically as $1 \mathrm{~K} \times 1 \mathrm{~K}$ data points using shifted squared-sinebell apodization windows. Typical sample concentrations for NOE analyses were in the range $8-450 \mathrm{mM}$. Probe temperature calibrations were performed using neat methanol samples containing a trace of $\mathrm{HCl}$ (below ambient) or with neat ethylene glycol (above ambient), and experiments were performed with active correction of the sample temperature set-points. Spectra were referenced to the residual ${ }^{1} \mathrm{H}$ solvent peak. ${ }^{1} \mathrm{H}$ NMR line shape simulations were performed using the gNMR $^{30}$ or SPINACH ${ }^{19}$ programs.

\section{ASSOCIATED CONTENT}

\section{S Supporting Information}

The Supporting Information is available free of charge on the ACS Publications website at DOI: 10.1021/acs.joc.6b00458.
Details of spectrum simulation methods, ${ }^{1} \mathrm{H}$ NOESY spectra, ${ }^{1} \mathrm{H}$, and ${ }^{13} \mathrm{C}$ characterization spectra (PDF)

\section{AUTHOR INFORMATION}

\section{Corresponding Authors}

*mark.moloney@chem.ox.ac.uk

*tim.claridge@chem.ox.ac.uk

\section{Author Contributions}

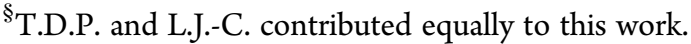

\section{Notes}

The authors declare no competing financial interest.

\section{ACKNOWLEDGMENTS}

L.J.C. received funding from the People Programme (Marie Curie Actions) of the European Union's Seventh Framework Programme (FP7/2007-2013) under REA grant agreement no. 316955. We also gratefully acknowledge funding under the MRC Confidence in Concept programme.

\section{REFERENCES}

(1) Royles, B. J. L. Chem. Rev. 1995, 95, 1981.

(2) Schobert, R.; Schlenk, A. Bioorg. Med. Chem. 2008, 16, 4203.

(3) Jeong, Y.-C.; Anwar, M.; Nguyen, T. M.; Tan, B. S. W.; Chai, C. L. L.; Moloney, M. G. Org. Biomol. Chem. 2011, 9, 6663.

(4) Andrews, M.; Brewster, A.; Crapnell, K.; Ibbett, A.; Moloney, M. G.; Jones, T.; Prout, K.; Watkin, D. J. Chem. Soc., Perkin Trans. 1 1998, 223.

(5) Andrews, M. D.; Brewster, A. G.; Moloney, M. G. Synlett 1996, 1996, 612.

(6) Anwar, M.; Moloney, M. G. Tetrahedron Lett. 2007, 48, 7259.

(7) Heaviside, E. A.; Moloney, M. G.; Thompson, A. L. RSC Adv. 2014, 4, 16233.

(8) Anwar, M.; Moloney, M. G. Chem. Biol. Drug Des. 2013, 81, 645.

(9) Fulop, F.; Pihlaja, K.; Mattinen, J.; Bernath, G. J. Org. Chem. 1987, $52,3821$.

(10) Fulop, F.; Pihlaja, K.; Neuvonen, K.; Bernath, G.; Argay, G.; Kalman, A. J. Org. Chem. 1993, 58, 1967.

(11) Fülöp, F.; Pihlajaa, K. Tetrahedron 1993, 49, 6701.

(12) Lázár, L.; Göblyös, A.; Martinek, T. A.; Fülöp, F. J. Org. Chem. 2002, 67, 4734.

(13) Jeong, Y.-C.; Anwar, M.; Bikadi, Z.; Hazai, E.; Moloney, M. G. Chem. Sci. 2013, 4, 1008.

(14) Neuhaus, D.; Williamson, M. P. The Nuclear Overhauser Effect in Structural and Conformational Analysis, 2nd ed.; Wiley: New York, 2000.

(15) Claridge, T. D. W. High-Resolution NMR Techniques in Organic Chemistry, 2nd ed.; Elsevier: Oxford, 2009.

(16) Perrin, C. L.; Dwyer, T. J. Chem. Rev. 1990, 90, 935.

(17) Kuprov, I.; Hodgson, D. M.; Kloesges, J.; Pearson, C. I.; Odell, B.; Claridge, T. D. W. Angew. Chem., Int. Ed. 2015, 54, 3697.

(18) Solomon, I.; Bloembergen, N. J. Chem. Phys. 1956, 25, 261.

(19) Hogben, H. J.; Krzystyniak, M.; Charnock, G. T. P.; Hore, P. J.; Kuprov, I. J. Magn. Reson. 2011, 208, 179.

(20) Kuprov, I. J. Magn. Reson. 2011, 209, 31.

(21) Goodwin, D. L.; Kuprov, I. J. Chem. Phys. 2015, 143, 084113.

(22) Lehn, J.-M.; Wagner, J. Tetrahedron 1970, 26, 4227.

(23) Lehn, J.-M. Fortsch. Chem. Forsch. 1970, 15, 311.

(24) Fukumi, T.; Arata, Y.; Fujiwara, S. J. Chem. Phys. 1968, 49, 4198.

(25) Arata, Y.; Fukumi, T.; Fujiwara, S. J. Chem. Phys. 1969, 51, 859.

(26) Seebach, D.; Sting, A. R.; Hoffmann, M. Angew. Chem., Int. Ed. Engl. 1996, 35, 2708.

(27) Seebach, D.; Aebi, J. D. Tetrahedron Lett. 1984, 25, 2545.

(28) Seebach, D.; Aebi, J. D.; Gander-Coquoz, M.; Naef, R. Helv. Chim. Acta 1987, 70, 1194.

(29) Jeanguenat, A.; Seebach, D. J. Chem. Soc., Perkin Trans. 1 1991, 2291. 
(30) Budzelaar, P. H. M. NMR simulation: gNMR. http://home.cc. umanitoba.ca/ budzelaa/gNMR/gNMR.html. 